\title{
Anatomical Variations and Morphometric Study of Pterion in a Thai Population Associated with Clinical Implications
}

\author{
Variaciones Anatómicas y Estudio Morfométrico del Pterion en \\ una Población Tailandesa Asociada con Implicaciones Clínicas
}

\author{
Siriwat Thunyacharoen ${ }^{1} \&$ Pasuk Mahakkanukrauh ${ }^{2,3}$
}

THUNYACHAROEN, S. \& MAHAKKANUKRAUH, P. Anatomical variations and morphometric study of pterion in a thai population associated with clinical implications. Int. J. Morphol., 39(4):1048-1053, 2021.

SUMMARY: The objective of this study was to consider the type of variation and to estimate the landmarks for localizing the pterion. One hundred twenty Thai dry skulls were selected randomly from the Forensic Osteology Research Center, Faculty of Medicine, Chiang Mai University. The distances of the parameters were measured via Vernier caliper. The sphenoparietal type is the most dominant in the Thai population with $88.75 \%$. In the male, the distance of the midglabella to the pterion was $9.94 \pm 0.64 \mathrm{~mm}$ The distance of the frontozygomatic suture to the pterion was $35.41 \pm 4.38 \mathrm{~mm}$ The distance of the zygomatic arch to the pterion was $39.39 \pm 4.69 \mathrm{~mm}$ and the distance of the mastoid process tip to the pterion was $86.88 \pm 4.44 \mathrm{~mm}$ In the female, the distance of the midglabella to the pterion was $9.27 \pm 0.63 \mathrm{~mm}$ The distance of the frontozygomatic suture to the pterion was $33.08 \pm 4.12 \mathrm{~mm}$ The distance of the zygomatic arch to the pterion was $33.08 \pm 4.12 \mathrm{~mm}$ and the distance of the mastoid process tip to the pterion was $83.62 \pm 5.16 \mathrm{~mm}$. The pterion approach is the most popular method for neurosurgical procedures, and it provides anatomical variations in the pattern. The sphenoparietal type of pterion is the most common form and the stellate type of pterion is the least common form in Thai skulls. Sex influences the location of the pterion. These findings will be of importance to predict the pterion type in Thai skull and estimate the localization of pterion by using a bony landmark. Knowledge of the precise location of the pterion is an important landmark in the neurosurgical approach.

KEY WORDS: Anatomical variation; Morphometry; Pterion.

\section{INTRODUCTION}

The pterion structure is a significant anatomical region for neurosurgical procedures on human skullat the lateral portion. The pterion is formed by the union of the intersection of the postero-inferior portion of frontal, greater wing or alisphenoid of the sphenoid, antero-inferior portion of parietal, and squamous portion of temporal bone and become an irregular $\mathrm{H}$-shaped union suture (Apinhasmit et al., 2011; Kamath et al., 2016). The pterion is resided behind to the frontozygomatic suture and perpendicularly superior to zygomatic arch (Adejuwon et al., 2013).

The pterion provides anatomical variations in the pattern of centralization of the intersection of four bones. Murphy's classification can divide the pterion into four types, sphenoparietal (the sphenoid and parietal bones are united); frontotemporal (the frontal and temporal bones are united); stellate (all the four bones join together) and epipteric or wormian, that is a small bone aggregate of all the bones together (Nayak et al., 2017). The epipteric (wormian) type can cause more weakness of the pterion type and contribute to the extension of the fractures (Natekar et al., 2011). The report declares that sphenoparietal pterion is the most common type, yet stellate pterion the least common (Kamath \& Hande, 2019).

However, the discrepancy in the precise morphometric location of the pterion are racial variations that can occur because of genetic or environmental domination (Adejuwon et al.). The pterion anatomical variations present due to some factors for example age,sex, ethnicity, and side of the skull (Ruiz et al., 2016). The present study aims to investigate the type of pterion variation via Murphy's classification and to measure the parameters of the landmarks for anatomical localizing the position of pterion in Thai dry skulls regarding sex and the side of the skull.

\footnotetext{
${ }^{1}$ Faculty of Medicine, Chiang Mai University, Chiang Mai, 50200, Thailand.

${ }^{2}$ Department of Anatomy, Faculty of Medicine, Chiang Mai University, Chiang Mai, 50200, Thailand.

${ }^{3}$ Excellence in Osteology Research and Training Center (ORTC), Chiang Mai University, Chiang Mai, 50200, Thailand.
} 
The objectives of this study are to consider the type of pterion variation via Murphy's classification and to measure the parameters of the landmarks for localizing the pterion in Thai dry skulls concerning sex and side of the skull. Knowledge of the precise anatomical position of pterion is an essential landmark in the neurosurgical approach and can be applied in the estimation of the precise location of the anterior division of the middle meningeal artery, middle cerebral artery, the Sylvian fissure, internal capsule, Broca's motor speech area on the left cerebral hemisphere and anterior pole of insula lobe (Moore et al., 2009; Apinhasmit et al.). The determination of the location via measurement of bony landmarks contribution from pterion may be of use to anatomists and neurosurgeons.

\section{MATERIAL AND METHOD}

Samples. The sampling was conducted randomly in a Thai population with sixty dry male skulls and sixty dry female skulls. This investigation conducted a cross-sectional descriptive study to research maxilla of human skull from the Forensic Osteology Research Center (FORC), Department of Anatomy, Faculty of Medicine, Chiang Mai University, Thailand. Collected maxilla samples were from adult cadavers (more than 20 years of age). The impaired bones or pathological bone for example traumatic fracture, osteoporosis, congenital anomalies, and bone cancer were dislodged in this investigation. The structure of the pterion was obvious and unbroken. The distances between pterion to midglabella, external occipital protuberance, frontozygomatic suture, zygomatic arch, and the tip of the mastoid process were measured and interpreted. We achieved approval from the Research Ethics Committee of Chiang Mai University (CODE: ANA-2563-07480).

Morphological-Osteometry. This study investigated the morphometric anatomical variations in the pterion and improved the knowledge of this region's anatomy and considered the precise location of the pterion by using external landmarks.

To locate the pterion, various parameters were measured on the specific landmarks of the lateral aspect of the skull by digital Vernier calipers of $0.02 \mathrm{~mm}$ accuracy on both sides of the pterion as in Figure 1.

Statistics Analysis. The various parameters demonstrated the locations of pterion were calculated to determine the mean \pm standard deviation and the frequency as in percentage (\%). The parameters were paralleled between the pterion in different sexes. Likewise, the parameters were analyzed between both sides of the pterion among total samples, male samples, and female samples.

All the previous parameters were calculated and analyzed via Microsoft Excel 2016 (Microsoft Corp., Redmond, WA, USA) and the program SPSS version 26 (SPSS Inc., Chicago, IL, USA). The descriptive statistical analysis of this study was applied for illustrating the central tendency (mean) and dispersion of data (S.D) and an independent sample t-test was applied to test of significance under $\mathrm{p}$-value $<0.05$ and $\mathrm{p}$-value $<0.05$ were considered as statistical significance.

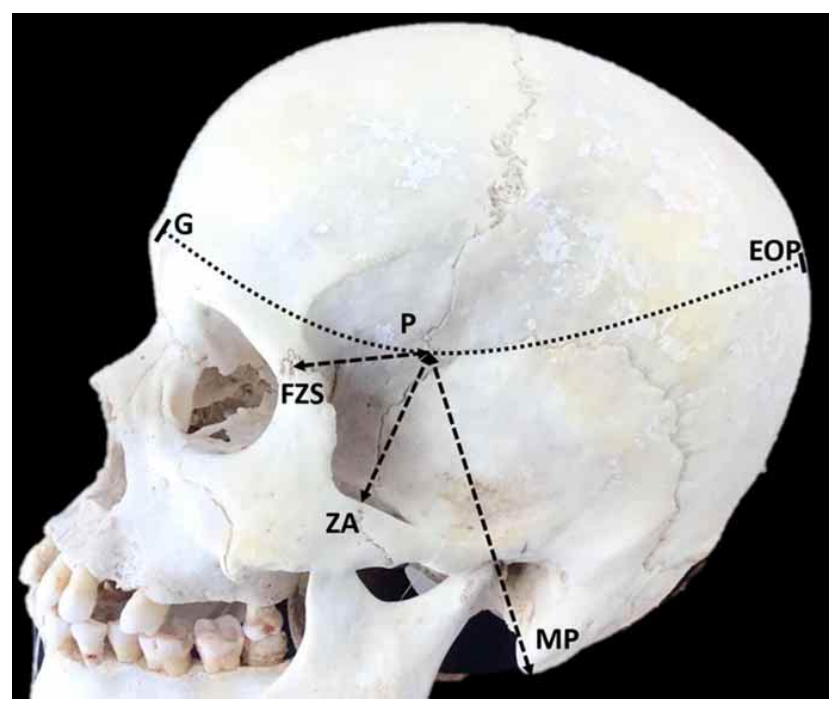

Fig. 1. Considered Parameters of Pterion Measurement, G-EOP: distance from the midglabella of the frontal bone to the external occipital protuberance of the occipital bone, G-P: distance from the midglabella of frontal bone to the pterion, P-EOP: distance from the pterion to the external occipital protuberance of the occipital bone, FZS-P: distance from the frontozygomatic suture to the pterion, ZA$\mathrm{P}$ : distance from the zygomatic arch to the pterion, MP-P: distance from the tip of the mastoid process to the pterion.

\section{RESULTS}

Incidence and Classification of the Pterion in the Lateral Compartment of the Skull. In this study, the pterion pattern of Thai skulls can be classified into four types in Figure 2. The incidence and classification of pterion in the lateral compartment of the skull are shown in Table I. In 120 skulls (240 sides of skulls), the Sphenoparietal type is the most dominant in the Thai population with $88.75 \%$. The second abundant type of pterion is the Epipteric type with $5 \%$ in the Thai population. The frontotemporal type can be found with $4.17 \%$ in the Thai population and the Stellate type is the least type of pterion form in the Thai population with $2.08 \%$. 
Table I. Pterion variation types in Thai population.

\begin{tabular}{lllll}
\hline Parameters & $\begin{array}{l}\text { Type } \\
\text { Sphenoparietal }\end{array}$ & Frontotemporal & Epipteric & Stellate \\
\hline Left side of male & $93.33 \%$ & $3.33 \%$ & $3.33 \%$ & $0 \%$ \\
Right side of male & $88.33 \%$ & $3.33 \%$ & $3.33 \%$ & $5 \%$ \\
Left side of female & $90 \%$ & $3.33 \%$ & $6.67 \%$ & $0 \%$ \\
Right side of female & $83.33 \%$ & $6.67 \%$ & $6.67 \%$ & $3.33 \%$ \\
Average & $88.75 \%$ & $4.17 \%$ & $5 \%$ & $2.08 \%$ \\
\hline
\end{tabular}

The Distance of Pterion to Various Parameter Measurements in Different Sexes. Pterion samples are classified by different sex; the mean and standard deviation of assorted parameters between male and female parameters were calculated and resulted in Table II. The comparison between different sexes has some statistically significant difference $(\mathrm{p}<0.05)$ in the ratio of G-P per P-EOP with $\mathrm{p}=$ 0.020603 in males and P-EOP in the female with $\mathrm{p}=$ 0.015271 . The ratio of pterion distance (between G-P per PEOP) of the left side of the lateral skull is more than the right side. The ratio was statistically significantly different. Likewise, the distance of P-EOP on the right side of the female skull is more than the left side with a statistically significant difference. Other parameters like G-P both sexes, $\mathrm{P}-E O P$ in male, Ratio in female, Pterion length both sexes, FZS-P both sexes, ZA-P both sex, MP-P both sexes was not a statistically significant difference.

In the male, all linear measurements were elucidated with the distance of the midglabella of frontal bone to the pterion (G-P) was $10.02 \pm 0.65 \mathrm{~mm}$ and $9.85 \pm 0.62 \mathrm{~mm}$ on the left and right side respectively. The distance of the pterion to the external occipital protuberance of the occipital bone (P-EOP) was $17.47 \pm 0.58 \mathrm{~mm}$ and $17.65 \pm 0.87 \mathrm{~mm}$ on the left and right side respectively. The ratio of pterion distance from G-P per P-EOP was calculated with $0.57 \pm 0.04 \mathrm{~mm}$ and $0.56 \pm 0.04 \mathrm{~mm}$ on the left and right side respectively. The pterion length was $12.57 \pm 4.53 \mathrm{~mm}$ and $11.81 \pm 3.73 \mathrm{~mm}$ respectively. The distance of the frontozygomatic suture to the pterion (FZS-P) was $35.04 \pm 4.26 \mathrm{~mm}$ and $35.78 \pm 4.5 \mathrm{~mm}$ on the left and right side respectively. The distance of the zygomatic arch to the pterion (ZA-P) was $39.51 \pm 3.44 \mathrm{~mm}$ and $39.28 \pm 5.7 \mathrm{~mm}$ on the left and right side respectively

Table II. Side comparison of the pterion.

\begin{tabular}{llccccc}
\hline & \multicolumn{3}{c}{ Male } & & \multicolumn{2}{c}{ Female } \\
& Light & Left & p-value \\
\hline G-P & $10.02 \pm 0.65$ & $9.85 \pm 0.62$ & 0.069661 & $9.26 \pm 0.66$ & $9.28 \pm 0.6$ & 0.43686 \\
P-EOP & $17.47 \pm 0.58$ & $17.65 \pm 0.87$ & 0.094523 & $16.88 \pm 0.88$ & $17.29 \pm 1.16$ & 0.015271 \\
Ratio & $0.57 \pm 0.04$ & $0.56 \pm 0.04$ & 0.020603 & $0.55 \pm 0.05$ & $0.54 \pm 0.05$ & 0.111737 \\
P terion length & $12.57 \pm 4.53$ & $11.81 \pm 3.73$ & 0.157392 & $12.08 \pm 4.03$ & $11.72 \pm 3.56$ & 0.306052 \\
FZS-P & $35.04 \pm 4.26$ & $35.78 \pm 4.5$ & 0.179916 & $32.78 \pm 4.26$ & $33.38 \pm 3.99$ & 0.211526 \\
ZA-P & $39.51 \pm 3.44$ & $39.28 \pm 5.7$ & 0.394206 & $38.35 \pm 3.61$ & $38.9 \pm 3.85$ & 0.210815 \\
MP-P & $86.87 \pm 4.4$ & $86.88 \pm 4.53$ & 0.496742 & $83.18 \pm 4.73$ & $84.06 \pm 5.57$ & 0.17548 \\
\hline
\end{tabular}

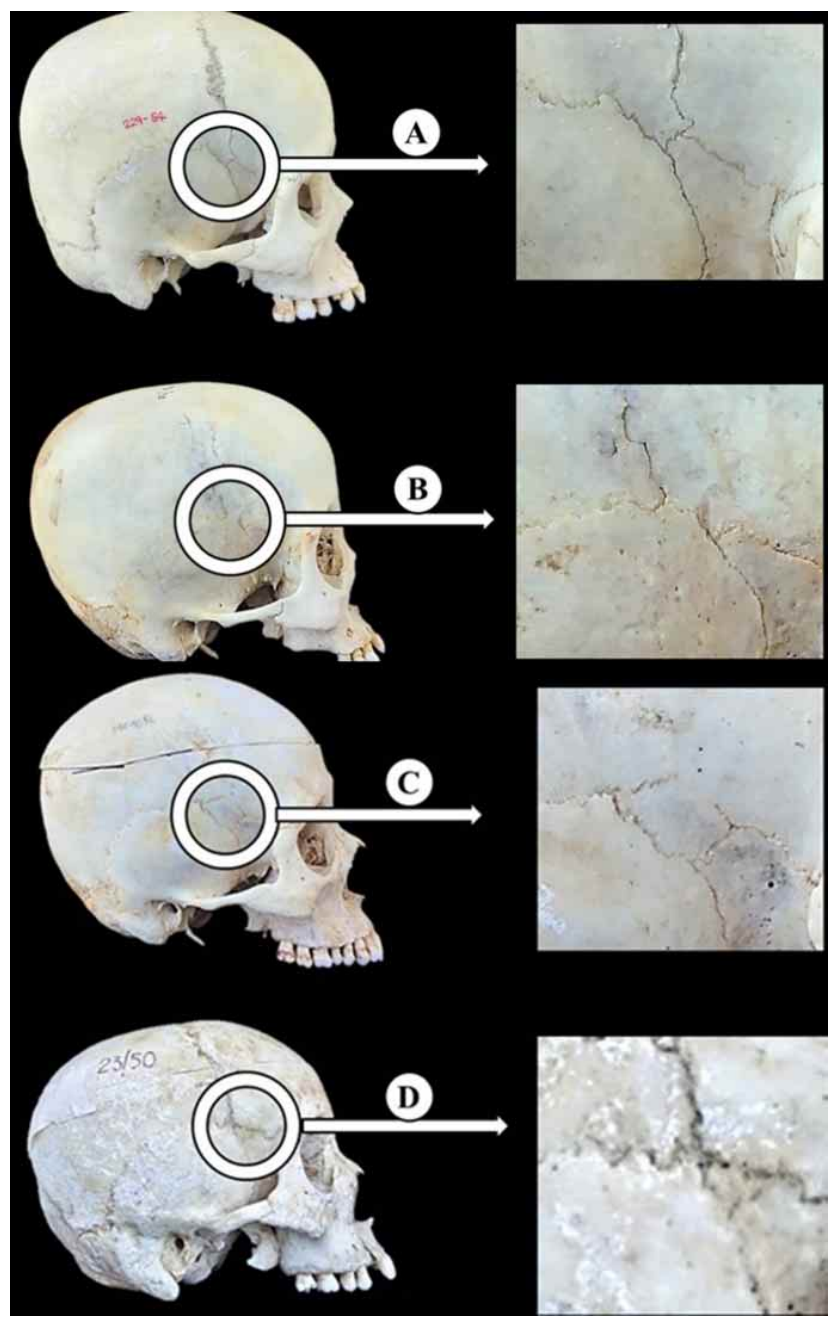

Fig. 2. Murphy's classification of pterion variation, $\mathrm{A}=$ sphenoparietal type, $\mathrm{B}=$ frontotemporal type, $\mathrm{C}=$ epipteric type and $\mathrm{D}=$ stellate type. 
and the distance of the tip of the mastoid process to the pterion. (MP-P) was $86.87 \pm 4.4 \mathrm{~mm}$ and $86.88 \pm 4.53 \mathrm{~mm}$ on the left and right side respectively.

In the female, all linear measurements were elucidated with the distance of the midglabella of frontal bone to the pterion (G-P) was $9.26 \pm 0.66 \mathrm{~mm}$ and $9.28 \pm 0.6$ $\mathrm{mm}$ on the left and right side respectively. The distance of the pterion to the external occipital protuberance of the occipital bone (P-EOP) was $16.88 \pm 0.88 \mathrm{~mm}$ and $17.29 \pm 1.16$ $\mathrm{mm}$ on the left and right side respectively. The ratio of pterion distance from G-P per P-EOP was calculated with $0.55 \pm 0.05$ $\mathrm{mm}$ and $0.54 \pm 0.05 \mathrm{~mm}$ on the left and right side respectively. The pterion length was $12.08 \pm 4.03 \mathrm{~mm}$ and $11.72 \pm 3.56 \mathrm{~mm}$ respectively. The distance of the frontozygomatic suture to the pterion (FZS-P) was $32.78 \pm 4.26 \mathrm{~mm}$ and $33.38 \pm 3.99$ $\mathrm{mm}$ on the left and right side respectively. The distance of the zygomatic arch to the pterion (ZA-P) was $38.35 \pm 3.61$ $\mathrm{mm}$ and $38.9 \pm 3.85 \mathrm{~mm}$ on the left and right side respectively and the distance of the tip of the mastoid process to the pterion. (MP-P) was $83.18 \pm 4.73 \mathrm{~mm}$ and $84.06 \pm 5.57 \mathrm{~mm}$ on the left and right side respectively.

Pterion and Sex-Comparison. Independent 2 samples t-test was applied to investigate the significant difference of parameters for sex discriminating in Table III.

The study enlightens a statistically substantial difference of pterion in the male skulls when compared with pterion of the females. The parameters of skull circumference such as G-P, P-EOP, and Ratio are statistically significant differences with $\mathrm{p}<0.05$. The FZS-P on both sides, ZA-P only on the left side, and MP-P on both sides are statistically significant differences with $\mathrm{p}<0.05$.

Table III. Sex comparison by pterion parameters.

\begin{tabular}{lcccccc}
\hline \multirow{2}{*}{ Parameters } & \multicolumn{3}{c}{ Left } & \multicolumn{3}{c}{ Right } \\
\cline { 2 - 7 } & Male & Female & p-value & Male & Female & p-value \\
\hline G-P & $10.02 \pm 0.65$ & $9.26 \pm 0.66$ & $<0.00001$ & $9.85 \pm 0.62$ & $9.28 \pm 0.6$ & $<0.00001$ \\
P-EOP & $17.47 \pm 0.58$ & $16.88 \pm 0.88$ & 0.000015 & $17.65 \pm 0.87$ & $17.29 \pm 1.16$ & $0.029 *$ \\
Ratio & $0.57 \pm 0.04$ & $0.55 \pm 0.05$ & 0.003178 & $0.56 \pm 0.04$ & $0.54 \pm 0.05$ & 0.008514 \\
Pterion length & $12.57 \pm 4.53$ & $12.08 \pm 4.03$ & 0.268112 & $11.81 \pm 3.73$ & $11.72 \pm 3.56$ & 0.447726 \\
FZS-P & $35.04 \pm 4.26$ & $32.78 \pm 4.26$ & 0.002099 & $35.78 \pm 4.5$ & $33.38 \pm 3.99$ & 0.001243 \\
ZA-P & $39.51 \pm 3.44$ & $38.35 \pm 3.61$ & 0.037983 & $39.28 \pm 5.7$ & $38.9 \pm 3.85$ & 0.338064 \\
MP-P & $86.87 \pm 4.4$ & $83.18 \pm 4.73$ & 0.00001 & $86.88 \pm 4.53$ & $84.06 \pm 5.57$ & 0.001432 \\
\hline
\end{tabular}

\section{DISCUSSION}

The present study in Thai with infratemporal fossa of 240 sides from 120 intact skulls illustrates that the most frequent variety of pterion type was Sphenoparietal (88.75 $\%)$, Frontotemporal (4.17 \%), Epipteric (5\%), and Stellate $(2.08 \%)$, respectively. This information is useful in neurosurgical consideration as Table IV.

The majority of the studies show the Sphenoparietal type is the most apparent in the infratemporal fossa of the lateral skull. Apinhasmit et al. observed the percentage of
Sphenoparietal type of pterion is $81.20 \%$, Frontotemporal type is $1.10 \%$, Epipteric type is $17.40 \%$ and Stellate type is 0.40 $\%$. Kamath et al. observed the percentage of sphenoparietal type of pterion is $79.25 \%$, the frontotemporal type is 10.25 $\%$, the stellate type is $6.30 \%$ and epipteric type is $4.20 \%$.

Adejuwon et al. acquired these results: $86.10 \%$ pterions were sphenoparietal type, followed by frontotemporal type $8.30 \%$, and stellate type with $5.60 \%$, no epiteric structure was observed. Nayak et al. obtained

Table IV. Comparison of Murphy's classification of pterion variation among racial groups.

\begin{tabular}{|c|c|c|c|c|c|}
\hline \multirow[t]{2}{*}{ Previous study } & \multicolumn{5}{|c|}{ Type } \\
\hline & Racial groups & Spheno-parie tal & Fronto-temporal & Epipteric & Stellate \\
\hline Apinhasmit et al. (2011) & Thai & $81.20 \%$ & $1.10 \%$ & $17.40 \%$ & $0.40 \%$ \\
\hline Adejuwon et al. (2013) & Nigeria & $86.10 \%$ & $8.30 \%$ & $0.00 \%$ & $5.60 \%$ \\
\hline Ruiz et al. (2016) & Brazil & $90 \%$ & $4.54 \%$ & $3.64 \%$ & $1.82 \%$ \\
\hline Kamath et al. (2016) & India & $79.25 \%$ & $10.25 \%$ & $4.20 \%$ & $6.30 \%$ \\
\hline Chaijaroonkhanarak et al. (2017) & Thai & $93.61 \%$ & $4.26 \%$ & $2.13 \%$ & $0.00 \%$ \\
\hline Nayak et al. (2017) & India & $85.00 \%$ & $0.00 \%$ & $10.00 \%$ & $5.00 \%$ \\
\hline Kamath \& Hande (2019) & India & $83.00 \%$ & $10.00 \%$ & $6.00 \%$ & $1.00 \%$ \\
\hline Present study & Thai & $88.75 \%$ & $4.17 \%$ & $5.00 \%$ & $2.08 \%$ \\
\hline
\end{tabular}


these results: $85.00 \%$ of pterions were sphenoparietal type, followed by epiteric type $10.00 \%$, stellate type with $5.00 \%$ and no frontotemporal type.

Kamath \& Hande observed the percentage of sphenoparietal type of pterion is $83.00 \%$, the frontotemporal type is $10.00 \%$, the epipteric type is $6.00 \%$ and stellate type is $1.00 \%$. Ruiz et al. obtained these results: $90 \%$ pterions were sphenoparietal type, followed by frontotemporal type $4.54 \%$, epiteric type with $3.64 \%$, and stellate type with $1.82 \%$. Chaijaroonkhanarak et al. (2017) acquired these results: $93.61 \%$ pterions were sphenoparietal type, followed by frontotemporal type $4.26 \%$, and epiteric type with $2.13 \%$, no stellate structure was observed.

For localization of pterion via neighbor parameters, measurements of pterion to other parameters are performed. In the present information, in males, the distance of the midglabella of frontal bone to the pterion (G-P) was $10.02 \pm 0.65 \mathrm{~mm}$ and $9.85 \pm 0.62 \mathrm{~mm}$ on the left and right sides respectively. The distance of the pterion to the external occipital protuberance of the occipital bone (P-EOP) was $17.47 \pm 0.58 \mathrm{~mm}$ and $17.65 \pm 0.87 \mathrm{~mm}$ on the left and right sides respectively. The ratio of pterion distance from G-P per P-EOP was calculated with $0.57 \pm 0.04 \mathrm{~mm}$ and $0.56 \pm 0.04$ $\mathrm{mm}$ on the left and right sides respectively. The pterion length was $12.57 \pm 4.53 \mathrm{~mm}$ and $11.81 \pm 3.73 \mathrm{~mm}$ respectively. The distance of the frontozygomatic suture to the pterion (FZS-P) was $35.04 \pm 4.26 \mathrm{~mm}$ and $35.78 \pm 4.5 \mathrm{~mm}$ on the left and right side respectively. The distance of the zygomatic arch to the pterion (ZA-P) was $39.51 \pm 3.44 \mathrm{~mm}$ and $39.28 \pm 5.7 \mathrm{~mm}$ on the left and right side respectively and the distance of the tip of the mastoid process to the pterion. (MPP) was $86.87 \pm 4.4 \mathrm{~mm}$ and $86.88 \pm 4.53 \mathrm{~mm}$ on the left and right sides respectively.

In the female, the distance of the midglabella of frontal bone to the pterion (G-P) was $9.26 \pm 0.66 \mathrm{~mm}$ and $9.28 \pm 0.6$ $\mathrm{mm}$ on the left and right sides respectively. The distance of the pterion to the external occipital protuberance of the occipital bone (P-EOP) was $16.88 \pm 0.88 \mathrm{~mm}$ and $17.29 \pm 1.16$ $\mathrm{mm}$ in the left and right side respectively. The ratio of pterion distance from G-P per P-EOP was calculated with $0.55 \pm 0.05$ $\mathrm{mm}$ and $0.54 \pm 0.05 \mathrm{~mm}$ on the left and right side respectively. The pterion length was $12.08 \pm 4.03 \mathrm{~mm}$ and $11.72 \pm 3.56 \mathrm{~mm}$ respectively. The distance of the frontozygomatic suture to the pterion (FZS-P) was $32.78 \pm 4.26 \mathrm{~mm}$ and $33.38 \pm 3.99$ $\mathrm{mm}$ on the left and right side respectively. The distance of the zygomatic arch to the pterion (ZA-P) was $38.35 \pm 3.61$ $\mathrm{mm}$ and $38.9 \pm 3.85 \mathrm{~mm}$ on the left and right side respectively and the distance of the tip of the mastoid process to the pterion. (MP-P) was $83.18 \pm 4.73 \mathrm{~mm}$ and $84.06 \pm 5.57 \mathrm{~mm}$ on the left and right sides respectively.
Apinhasmit et al. recorded the location of pterion externally. The pterion was established $38.48 \pm 4.38 \mathrm{~mm}$ to the superiorly zygomatic arch and $31.12 \pm 4.89 \mathrm{~mm}$ to the posteriorly frontozygomatic suture with an average length of pterion sutures was $11.56 \pm 4.51 \mathrm{~mm}$.

Kamath et al. declared the location of pterion with a average distance of the center of the pterion from the zygomatic bone was $36.85 \pm 4.12 \mathrm{~mm}$ and $34.35 \pm 3.18 \mathrm{~mm}$ in males and females respectively. The linear distance measurement from frontozygomatic suture was $31.90 \pm 4.14$ $\mathrm{mm}$ and $29.72 \pm 3.75 \mathrm{~mm}$ in males and females respectively.

Adejuwon et al. measured the average distances from the pterion externally to the midpoint of the zygomatic arch were $39.74 \pm 0.505 \mathrm{~mm}$ and $37.95 \pm 0.657 \mathrm{~mm}$ in males and females, respectively. Also, the linear mean distances to the frontozygomatic suture were $31.87 \pm 0.642 \mathrm{~mm}$ and 30.35 $\pm 0.836 \mathrm{~mm}$ in males and females, respectively.

Kamath \& Hande claimed the midpoint of pterion was situated at an average distance of $37.02 \mathrm{~mm}$ above the middle of the zygomatic arch, $28.20 \mathrm{~mm}$ behind the posterolateral margin of the frontozygomatic suture. The data obtained will be useful for identifying the pterion location for neurosurgery.

\section{ACKNOWLEDGEMENTS}

The authors are very thankful to the support from Forensic Osteology Research Center, Faculty of Medicine, Chiang Mai University, and partially supported from the Excellence in Osteology Research and Training Center (ORTC), Chiang Mai University.

THUNYACHAROEN, S. \& MAHAKKANUKRAUH, P. Variaciones anatómicas y estudio morfométrico de Pterion en una población tailandesa asociada con implicaciones clínicas. Int. J. Morphol., 39(4):1048-1053, 2021.

RESUMEN: El objetivo de este estudio fue considerar el tipo de variación del pterion y estimar los puntos de referencia para localizarlo. Se seleccionaron al azar 120 cráneos secos de individuos tailandeses del Centro de Investigación de Osteología Forense de la Facultad de Medicina de la Universidad de Chiang Mai. Las distancias de los parámetros se midieron mediante un caliper Vernier. El tipo esfenoparietal es el más dominante en la población tailandesa con $88,75 \%$. En el hombre, la distancia de la glabella al pterion fue de $9,94 \pm 0,64 \mathrm{~mm}$. La distancia de la sutura frontocigomática fue de 35,41 \pm 4,38 mm La distancia del arco cigomático fue de $39,39 \pm 4,69 \mathrm{~mm}$ y la distancia del ápice del proceso mastoideo al pterion fue de $86,88 \pm 4,44 \mathrm{~mm}$. En la mujer, 
la distancia de la glabella al pterion fue de 9,27 $\pm 0,63 \mathrm{~mm}$. La distancia de la sutura frontocigomática al pterion fue de 33,08 \pm $4,12 \mathrm{~mm}$. La distancia del arco cigomático al pterion fue de 33,08 $\pm 4,12 \mathrm{~mm}$ y la distancia del ápice proceso mastoideo al pterion fue de 83,62 $\pm 5,16 \mathrm{~mm}$. El abordaje del pterion es el método más utilizado para procedimientos neuroquirúrgicos y proporciona variaciones anatómicas en el patrón. El tipo esfenoparietal del pterion es la forma más común y el tipo estrellado del pterion es la forma menos común en los cráneos tailandeses. El sexo influye en la ubicación del pterion. Estos hallazgos serán importantes para predecir el tipo de pterion del cráneo en tailandeses y a la vez estimar su localización mediante el uso de un punto de referencia óseo. El conocimiento de la ubicación precisa del pterion es un hito importante en el abordaje neuroquirúrgico.

PALABRAS CLAVE: Variación anatómica; Morfometría; Pterion.

\section{REFERENCES}

Adejuwon, S. A.; Olopade, F. E. \& Bolaji, M. Study of the location and morphology of the pterion in adult Nigerian skulls. Int. Sch. Res. Not., 2013:403937, 2013.

Apinhasmit, W.; Chompoopong, S.; Chaisuksunt, V.; Thiraphatthanavong, P. \& Phasukdee, N. Anatomical consideration of pterion and its related references in Thai dry skulls for pterional surgical approach. J. Med. Assoc. Thai., 94(2):205-14, 2011.

Chaijaroonkhanarak, W.; Woraputtaporn, W.; Prachaney, P.; Amarttayakong, P.; Khamanarong, K.; Pannangrong, W.; Welbat, J. U. \& Iamsaard, S. Classification and incidence of pterion patterns of Thai skulls. Int. J. Morphol., 35(4):1239-42, 2017.

Kamath, V.; Asif, M.; Bhat, S. \& Avadhani, R. A study on the pterion position variation and its neurosurgical implications. J. Anat. Soc. India., 65 Suppl. 1:S33-9, 2016.

Kamath, V. G. \& Hande, M. Reappraising the neurosurgical significance of the pterion location, morphology, and its relationship to optic canal and sphenoid ridge and neurosurgical implications. Anat. Cell Biol., 52(4):406-13, 2019.

Moore, K. L.; Dalley, A. F. \& Agur, A. M. R. Clinically Oriented Anatomy. 6th ed. Philadelphia, Wolters Kluwer Health/Lippincott Williams \& Wilkins, 2009.

Natekar, P. E.; De Souza, F. M. \& Natekar, S. P. Pterion: An anatomical variation and surgical landmark. Indian J. Otol., 17(2):83-5, 2011.

Nayak, G.; Mohanty, B. B. \& Das, S.R. Morphometric study of pterion and its clinical significance. Asian J. Pharm. Clin. Res., 10(10):142-4, 2017.

Ruiz, C. R.; Souza, G. C.; Scherb, T. O. \& Nascimento, S. R. R. Anatomical variations of pterion: Analysis of the possible anatomical variations of pterion in human skulls. J. Morphol. Sci., 33(4):200-4, 2016.
Corresponding author:

Professor (distinguished) Pasuk Mahakkanukrauh

MD, Department of Anatomy

Faculty of Medicine

Chiang Mai University

Chiang Mai

THAILAND

E-mail: pasuk034@gmail.com

Received: 11-04-2021

Accepted: 11-05-2021 